\title{
接線剛性行列を用いたモード分解に基づく下層部変形集中メカニズムの検討 EXAMINING MECHANISMS BEHIND DEFORMATION CONCENTRATION INTO LOWER STORIES BASED ON MODAL DECOMPOSITION USING TANGENT STIFFNESS MATRIX
}

\author{
三 崎 洋 輔*, 岡山真之介**, 荒木 慶一***, 上谷宏二**** \\ Yosuke MISAKI, Shinnosuke OKAYAMA, Yoshikazu ARAKI \\ and Köi UETANI
}

\begin{abstract}
When high-rise buildings are subjected to intense earthquake ground motions, deformation concentrates into a restricted lower part of a building frame in the process of collapse even though it is designed in accordance with the strong-column-weak-beam concept. This paper examines the mechanisms behind the deformation concentration based on the modal decomposition of displacement increment using the tangent stiffness matrix. An improved criterion is proposed for predicting the deformation concentration region based on the presented mechanism. Furthermore, this paper studies the influence of large rotation and column yielding on dynamic collapse, which were neglected in the above examination.
\end{abstract}

Keywords : deformation localization, high-rise building, modal analysis, buckling analysis, structural instability 変形集中, 超高層骨組, モ一ド解析, 座屈解析, 構造不安定

\section{1. 序}

近年, 従来の研究や設計の想定を大きく上回る地震動が国内外で 観測されている ${ }^{1,2)}$. 我国に限っても，1995 年兵庫県南部地震など の直下地震では， 1 秒程度以上の比較的長周期の特定の周期帯で極 めて大きなパワーを持つパルス性地震動が観測されている。また， 南海トラフ地震などの海溝型巨大地震により, 大都市圈において数 秒程度の特定の周期帯で大きなパワーを持ち継続時間が数分にわた る長周期地震動が発生する危険性が指摘されている。このような状 況で，これら従来の想定を大きく上回る「高レベル地震動」に対す る建築物の耐震安全性確保が喫緊の社会的要請となっている.

上谷と田川 ${ }^{3,4)}$ は超高層鋼構造建築物の強震応答に関する検討を 行い, 当時のレベル 2 設計用地震動を係数倍した過大入力の下では, 梁降伏型の崩壊機構を想定して設計された建物においても，下層部 の複数層にまたがる弓型変形モードが発生し，この変形モードが一 方向に累積する危険性を指摘している。 この現象は, 上谷と田川に より「下層部変形集中現象」と名づけられている．また，変形集中 が発生する領域を予測する条件式を, Euler 座屈と同様の座屈条件式 の形で誘導し, 時刻歴応答解析結果との比較により妥当性を例証し ている. しかし, 動的載荷時に下層部変形集中現象が発生するメカ ニズム（以下，「下層部変形集中メカニズム」と呼ぶ）を説明するに は至っていない。
金ら 5) と荒木ら ${ }^{6)}$ は, 我国の構造設計実務の実情をふまえた現実 的な超高層鋼構造骨組を多数設計し，時刻歴応答解析により下層部 変形集中現象に対する余裕度を検討した。 その結果, 建築基準法レ ベルの地震動の下では下層部変形集中現象は発生しないものの, 高 レベル地震動の下では余裕度が必ずしも高いとは言えないことを示 した。このような状況で，下層部変形集中メカニズムの理解を深め ることは，建築構造学における重要課題の一つである.

本論文では, 動的載荷時における下層部変形集中メカニズムに関 して, 接線剛性行列を用いた変位増分のモード分解に基づく検討を 行う。また，検討結果に基づき既往の座屈条件式よりも変形集中領 域を良好な精度で予測可能な修正座屈条件式を誘導し，振動固有値 解析及び時刻歴応答解析の結果との比較により修正座屈条件式の妥 当性を検証する. さらに, 柱の塑性化（第 1 層柱脚以外）の影響や, 幾何非線形の扱いが応答に及ぼす影響についても検討を行う.

\section{2. 骨組モデル}

本論文では比較のため既往の研究 ${ }^{7)}$ と同一の解析モデルを用いる. 水平方向に無限均等な部材配置を持つ 30 層多スパン平面骨組を考 え, そこから 1 スパン分を取り出した図 1(a)に示す 30 層魚骨形部分 骨組モデルを解析対象とする．第 $i$ 層の柱梁接合部に集中荷重 $m_{i}$ を 配置する．この質量により第 $i$ 層の柱梁接合部に重力 $m_{i} g \quad(g$ :重力
* 京都大学大学院工学研究科建築学専攻 大学院生

** 大成建設設計本部

*** 京都大学大学院工学研究科建築学専攻 准教授・博士 (工学)

$* * * *$ 摂南大学 教授 $\cdot$ 博士 (工学)
Graduate Student, Dept. of Architecture and Architectural Eng., Kyoto Univ. Design Dept., Taisei Corporation

Assoc. Prof., Dept. of Architecture and Architectural Eng., Kyoto Univ., Dr. Eng.

Prof., Setsunan Univ., Dr. Eng. 
加速度）が作用する. 第 $i$ 層の柱の曲げ剛性を $E I_{c i}$, 第 $i$ 層の梁の曲 げ剛性を $E I_{g i}$, 全ての梁部材の長さを $2 l$, 第 $i$ 層柱梁接合部の地表 からの高さを $h \times i$ とする. 図1(b)に示す梁降伏型の崩壊機構を想定 する. 図 2 (a)に示寸第 $i$ 層の梁端の曲げモーメント $M_{g i}$ と回転角 $\theta_{g i}$ の関係は図 2 (c) に示すように初期剛性を $K_{i}$ とし, 降伏後の剛性は第 二分枝勾配比を $\alpha$ として $\alpha K_{i}$ とする. 梁の全塑性モーメントを $M_{g i}^{p}$ で表す. 図 2(b)に示す最下層柱脚部の曲げモーメント $M_{c}$ と塑性ヒ ンジ回転角 $\varphi_{c}$ との関係は, 図 $2(d)$ に示す完全剛塑性を想定し, 全塑 性モーメントを $M_{c}^{p}$ で表す. 5.3 節までは第 1 層柱脚以外の部分で柱 の塑性化は発生しないと仮定して解析を行う。この仮定の妥当性は 5.4 節で検討する。骨組の運動方程式は以下のように書ける.

$$
[M]\{\ddot{u}\}+[C]\{\dot{u}\}+\{f\}=-[M]\{1\} \ddot{u}_{g}
$$

ここで $[M]$ は質量行列, $[C]$ は減衰行列, $\{f\}$ は復元力ベクトル, $\{u\}$ は変位ベクトル， $\ddot{u}_{g}$ は地動加速度, $\{1\}$ は全成分が 1 のベクトルで ある. 上付きドットは時刻 $t$ に関する微分を表す，骨組の断面諸量 を表 1 に示す. 1 次と 2 次の固有周期は 3.39 秒, 1.16 秒である.

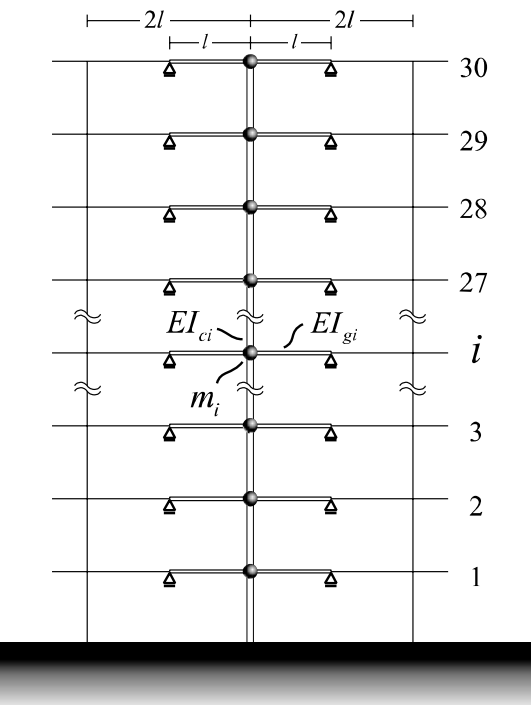

図 1 (a) 30 層魚骨骨組

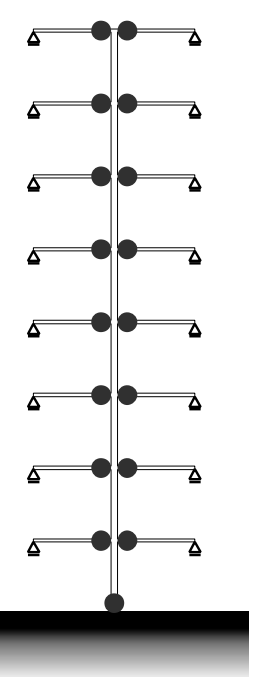

(b) 塑性ヒンジ位置

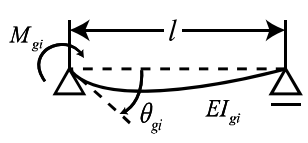

(a)

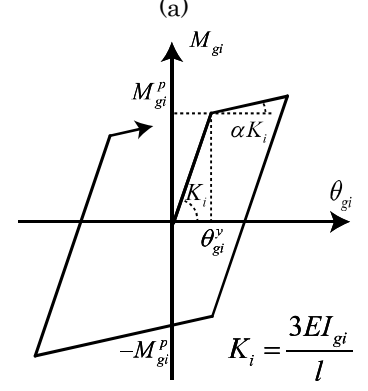

(c)

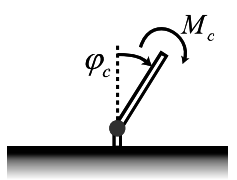

(b)

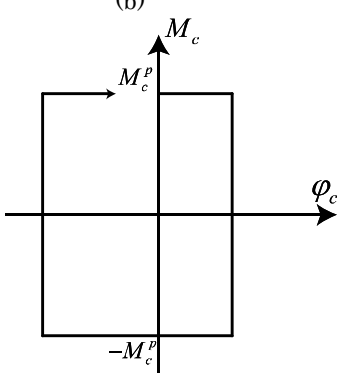

(d)
図 2 柱と梁の部材端回転角と曲げモーメントの関係
表 1 骨組断面諸量

\begin{tabular}{ccc}
\hline & $1 \sim 15 \mathrm{~F}$ & $16 \sim 30 \mathrm{~F}$ \\
\hline \hline$I_{c i}\left(\mathrm{~cm}^{4}\right)$ & 550000 & 300000 \\
\hline$I_{g i}\left(\mathrm{~cm}^{4}\right)$ & 140000 & 130000 \\
\hline$M_{c i}^{P}(\mathrm{kN} \cdot \mathrm{m})$ & & 3920 \\
\hline$M_{g i}^{P}(\mathrm{kN} \cdot \mathrm{m})$ & 1372 & 1274 \\
\hline 柱梁耐力比 & 2.85 & 3.07 \\
\hline$m_{i}($ ton $)$ & & \\
\hline$h(\mathrm{~m})$ & & 3 \\
\hline$l(m)$ & & \\
\hline
\end{tabular}

\section{3. 下層部変形集中メカニズム}

\section{1 接線剛性行列を用いた振動固有值解析}

下層部変形集中メカニズムを検討するため, 塑性化が生じた後の 接線剛性行列を用いた振動固有值解析を行う。図 1(b)に示すように 1 層柱脚及び各層の梁端部の塑性化のみを想定すると, 考えうる塑 性ヒンジ分布は $N$ 層骨組で $2^{(N+1)}$ 通り存在する。しかし，下層部変 形集中現象に関連があるのは，下層部の数層が塑性化した場合であ ることから，この全てに関して固有值解析を行うのではなく, 1 層 柱脚， 2 層梁端， 3 層梁端...と下から順に塑性化領域を広げていき, その都度の接線剛性行列を用いて計 $N$ 回の振動固有值解析を行う. 非減衰の振動固有值問題は以下のようにかける.

$$
-\Omega[M]\{\Phi\}+\left(\left[K_{m t}\right]-\left[K_{g}\right]\right)\{\Phi\}=\{0\}
$$

ここで $\left[K_{m t}\right]$ は材料接線剛性行列, $\left[K_{g}\right]$ は幾何剛性行列 ${ }^{8)}, \Omega$ は振 動固有值， $\{\Phi\}$ は振動固有モードベクトルである。この時, $\left[K_{t}\right]=\left[K_{m t}\right]-\left[K_{g}\right]$ が接線剛性行列となる． $\Omega$ が正となるモード変位 $q$ の一般解は振動を表す調和関数（三角関数）となるが， $\Omega$ が負す なわち $\Omega<0$ となるモード変位 $q$ の一般解は発散挙動を表す指数関 数となる. 外力が作用しない場合の $\Omega<0$ の時の解を以下に示寸. $q$ と $\Omega$ を用いて運動方程式は以下のように書ける.

$$
\ddot{q}+\Omega q=0
$$

$q=X e^{\lambda t}$ を代入し，任意の時刻 $t$ について成り立つとすると

$$
\lambda^{2}+\Omega=0 \Leftrightarrow \lambda= \pm \sqrt{-\Omega}
$$

となり， $\Omega$ は負であるため $\lambda$ は実数となる,よって一般解は次のよ うに時刻 $t$ に関する指数関数の重站わせとして表せる.

$$
q=c_{1} e^{\sqrt{-\Omega} t}+c_{2} e^{-\sqrt{-\Omega} t} \quad\left(c_{1}, c_{2} \text { は実数 }\right)
$$

初期モード変位を $q_{0}$ ，初期モード速度を $\dot{q}_{0}$ とすると，上式は

$$
q=\left\{q_{0} / 2+\dot{q}_{0} /(2 \sqrt{-\Omega})\right\} e^{\sqrt{-\Omega} t}+\left\{q_{0} / 2-\dot{q}_{0} /(2 \sqrt{-\Omega})\right\} e^{-\sqrt{-\Omega} t}
$$

となる．上式第 1 項は $t$ に関する単調増加の指数関数であり， $\Omega$ の 絶対值が大きいほど変位の増大率が大きい。一方，第 2 項は単調減 少の指数関数であり, $t$ の増加に伴い第 1 項と比較して無視できる ようになる.なお, 既往の研究では, 1 自由度系では $\Omega<0$ となると 変形が一方向に累積するドリフト現象が発生することが指摘されて いる ${ }^{9)}$.また，多自由度系では $\Omega<0$ となると変形が局所化するこ とや ${ }^{10)}, \Omega<0$ が倒壊の必要条件であることが指摘されている ${ }^{11)}$. 


\section{2 メカニズムの考察}

接線剛性行列を用いた振動固有値解析の結果に基づき, 下層部変 形集中メカニズムについて考察する. 図 3 は 2 章の 30 層骨組に対し 第一層柱脚もしくは各層梁端の第二分枝勾配比を $\alpha=0$ として, 塑 性化領域を下から順に高くし固有值解析を行った時の 1 次の固有値 と固有モードの変化を示している. 各図の灰色の丸は各層梁端の塑 性化を示す. 幾何非線形効果を無視した場合（式(1)で $\left[K_{g}\right]=[0]$ と した場合）の結果を図 3(a)に, 幾何非線形効果を考慮した場合の結 果を図 3(b)に示す. 幾何非線形効果を考慮した場合, 塑性化する層 の領域が大きくなると, 図 3(b)に示すように 1 次振動固有值 $\Omega$ が負 となり, 梁端の回転角が反転する折り返し点（○で図示）が 1 次固 有モード中に現れる. 一方, 図 3(a)に示すように, 幾何非線形を無 視した場合, 1 次振動固有值は常に正であり, 固有モードに折り返 し点が現れない． 3.1 節で示したように, 外力が作用しない時は負 の固有值に対応する固有モードが時刻 $t$ に関して指数関数的に成長 する. 塑性化領域が低く固有モードに折り返し点が無い場合（例え ば 9 層以下が塑性化した場合, 図 3(b)左), 全ての塑性ヒンジが負荷 挙動を示したままで変形が進む。一方, 固有モードに折り返し点が ある場合（例えば 14 層以下が塑性化した場合, 図 3(b)右), この変

0-9 層塑性化 $\Omega^{\mathrm{NPD}}$
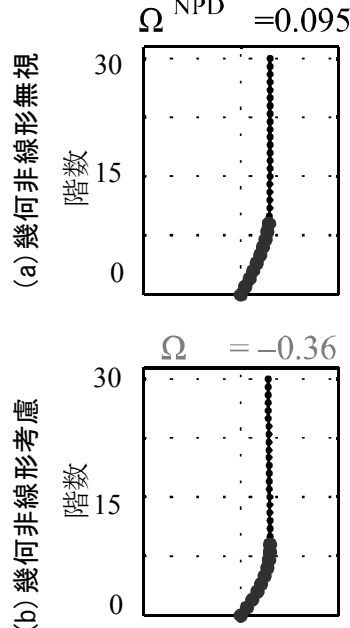

0-10 層塑性化 $\Omega^{\mathrm{NPD}}=0.074$

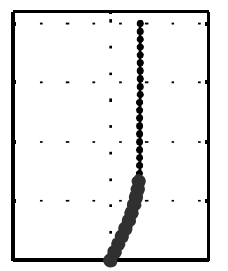

0-14 層塑性化 $\Omega^{\mathrm{NPD}}=0.033$
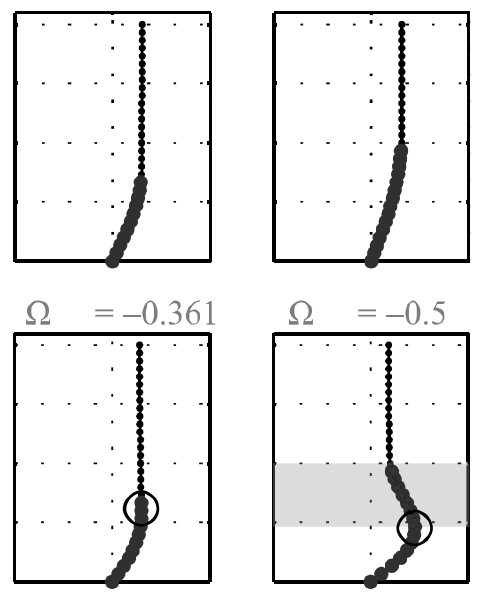

1 次固有モード

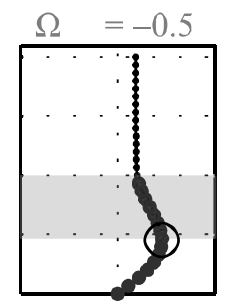

図 3 振動固有値解析

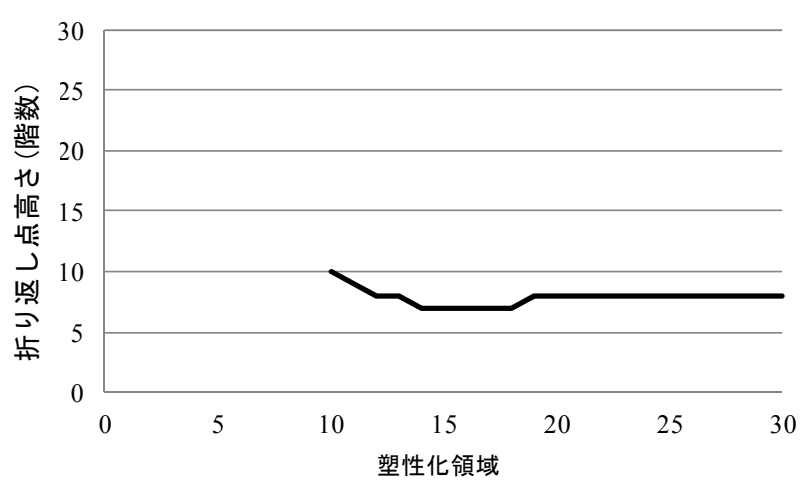

図 5 塑性化領域と折り返し点高さの関係
形モードが卓越すると折り返し点より上の網掛部分では塑性ヒンジ が弾性除荷挙動を示寸.このため, 図 4 に示すように梁端の回転角 が 0 で塑性ヒンジが負荷も除荷も生じない「中立負荷」となる折り 返し点より上では，瞬間的に塑性化が発生することがあってもモー ドの成長に伴い除荷が発生するため塑性負荷挙動が継続することは ない，さらに，図 5 に示すように，塑性化領域を下から順に高くし ていくと，10 層に到達した時に折り返し点が現れ，それ以上に塑性 化領域を高くしても折り返し点の高さは大きく変化しない。これら のことが, 下層部の一定の領域に変形が集中寸るメカニズムである.

なお，外力が作用しない場合の運動は 1 次の固有モードのみでは なく, より高次を含む全ての振動固有モードの重㸚合わせとして記 述される。しかし，最小振動固有值が負となる時は，最小振動固有 值に対応する固有モードが最も大きく指数関数的に成長し，時刻の 経過に伴い卓越する。なお，地震応答などの強制振動の下では，強 制振動に伴う特解が存在するため上記のメカニズムのみでは挙動を 完全に説明できない。しかし，既往の研究 ${ }^{10)}$ で指摘されているよ うに，一般に，強制振動時にも負となる固有值に対応寸る固有モー ドの変形が卓越する。本論文では 5.3.3 節において, 正弦波地動を 受ける場合について時刻歴応答解析を行い，強制振動時における提 案メカニズムの妥当性を検討する.
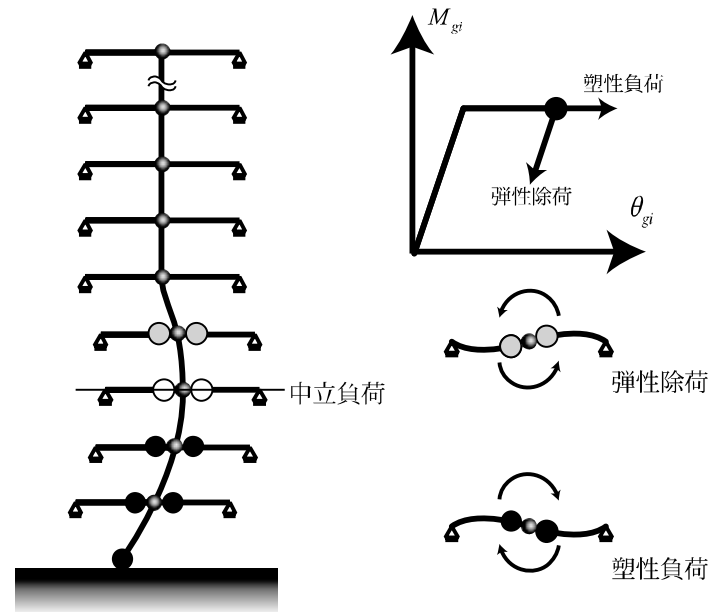

図 4 折り返しによる梁端塑性ヒンジの除荷・負荷・中立負荷

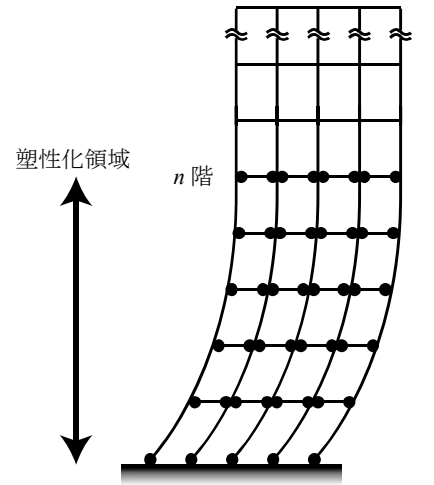

（a）全体骨組

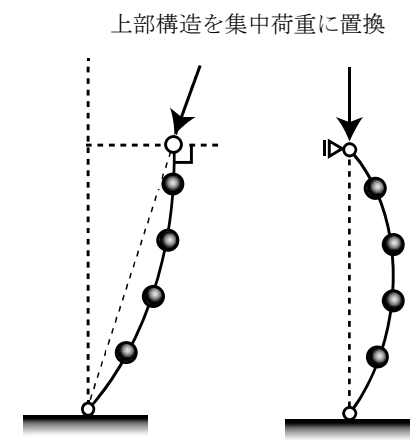

（b）本報等価骨組 (c) 既往等価骨組

図 6 等価座屈モデル 


\section{4. 修正座屈条件式}

上谷と田川 ${ }^{3,4}$ は，準静的及び動的繰返し載荷を与えた時の弓形 変形の発生に関する検討結果 ${ }^{12-16)}$ と, 下層部変形集中現象が発生し た時のモーメント分布（変形集中領域上端でモーメント 0）との比 較に基づき,変形集中領域の高さを予測する座屈条件式を誘導した. 本章では, 3 章の考察に基づき, 修正座屈条件式を提案する.

\section{1 等価座屈モデルの座屈固有值解析}

図 6 に示寸等価座屈モデルに対し部材塑性化時の接線剛性行列を 用いた座屈固有值解析を行う. 1 層梁端, 2 層梁端部...と順に塑性化 領域を高くしていき, その都度, 塑性化領域のみを取り出した部分 骨組の接線剛性行列を用いて, 以下の線形座屈固有值解析を行う.

$$
\left(\left[\tilde{K}_{m t}\right]-\Lambda\left[\tilde{K}_{g}\right]\right)\{\tilde{\Phi}\}=\{0\}
$$

ここで, $\left[\tilde{K}_{m t}\right]$ と $\left[\tilde{K}_{g}\right]$ は部分骨組の材料接線剛性行列と幾何剛性行 列, $\{\tilde{\Phi}\}$ は部分骨組の座屈固有モードである. $\Lambda$ は座屈固有值であ り, 物理的には鉛直荷重の荷重係数を表す。 $\left[\tilde{K}_{g}\right]$ は自重による鉛直 荷重 $(\Lambda=1)$ で発生する柱軸力に起因する幾何剛性行列であり, $\Lambda \leq 1$ の場合, 部分骨組は自重により座屈寸る. 塑性化領域が高くな るにつれて $\Lambda$ の值は低下寸る. 変形集中領域は $\Lambda$ が初めて 1 以下 となる時の塑性化領域の高さ (=部分骨組の高さ) として得られる.

図 6(c)に示すように, 既往の座屈条件式 ${ }^{3,4)}$ では, 以下の境界条 件を用いて部分骨組の座屈固有值解析を行う.

- 1 層柱脚節点 : 水平変位 $=0$, モーメント $=0$

- 部分骨組最上層柱頭節点 : 水平変位 $=0$, モーメント $=0$ 注 1$)$

一方, 図 6(b)に示すように, 本論文で提案する座屈条件式では, 以 下の境界条件の下で部分骨組の座屈固有值解析を行う。

- 1 層柱脚節点 : 水平変位 $=0$, モーメント $=0$

- 部分骨組最上層柱頭節点 : 回転角 $=0$, モーメント $=0$

部分骨組最上層柱頭節点において, 「変位 $=0 」$ を「回転角 $=0 」$ に置 き換えた点が修正点である. 修正座屈条件式における境界条件で座 屈固有值問題を解くに際に必要な処理を Appendix1 に示寸.

修正後の境界条件は以下の二点の特徵を持つ。（1）部分骨組最上 層柱頭節点の「回転角 $=0 」$ の条件は, 該当寸る層の梁端の塑性ヒン ジが中立負荷であることと対応する．この条件は, 動的状況下で塑 性化領域の推移が落ち着き, 同じ塑性化領域の下で変形が大きく進 む（塑性化領域う折り返し高さとなる）状態に対応するように設定 している注 2). (2) 修正座屈条件式では部分骨組最上層柱頭のモーメ ント ( $\propto$ 曲率 $)$ と回転角が 0 で, 水平変位が拘束されていないため, 図 6(a)のように部分骨組よりも上部の骨組が剛体として水平移動す る座屈モードを直接表現できる。一方, 既往座屈条件式においてこ の座屈モードを表現するためには，不定である座屈モードの大きさ に応じて部分骨組の座屈モードを剛体回転させる必要がある.

\section{5. 時刻歴応答解析}

\section{1 解析の概要と設定}

2 章の 30 層骨組を対象に時刻歴応答解析を行う。 5.2 節では，初 速度入力時の運動を対象として接線剛性行列を用いたモード分解を 行い, 3 章で示した下層部変形集中メカニズムの妥当性を検証する. 5.3 節では, 周期地動入力時の強制振動を対象として, 4 章で示した
修正座屈条件式の妥当性を検証する. 5.4 節では, 幾何非線形効果 や柱の塑性化の扱いの差異が応答予測に及ぼす影響について検討す る.なお， 5.2 節と 5.3 節では，下層部変形集中メカニズムの検討を 明快に行うため, 第 1 層柱脚以外で柱には塑性ヒンジが発生しない との仮定のもとで解析を行うが， 5.4 節ではこのような仮定を設け ず解析を行い，仮定の有無による解析結果の相違を比較する.

時刻歴応答解析のパラメータの設定は以下の通りである。減衰定 数 0.02 の初期剛性比例型減衰とする. 運動方程式の時間積分には平 均加速度法を用い, 時間刻みは 0.002 秒とする. 各時間ステップに おいて Newton 法により不釣合力を解消する．弾塑性構成則の時間 積分には 1 次元 Return-Mapping 法を用いる ${ }^{17)}$.

\section{2 下層部変形集中メカニズムの検証}

\section{2 .1 変位増分のモード分解}

変位増分 $\left\{\Delta u_{i}\right\}$ を次式で定義する.

$$
\left\{\Delta u_{i}\right\}=\left\{u_{i+1}\right\}-\left\{u_{i}\right\}
$$

ここで， $\Delta \tau$ は変位増分の時間間隔を指定する值であり, $\left\{u_{i}\right\}$ は時刻 $t=i \Delta \tau$ における系の変位ベクトルである. $\Delta \tau$ は平均加速度法の時 間刻みとは一般に異なる. 式(2)の接線剛性行列を用いた固有値問題 を解いて得られる固有モードを用いて, 式(8)の変位増分 $\left\{\Delta u_{i}\right\}$ は以 下のようにモード分解できる。

$$
\left\{\Delta u_{i}\right\}=\Delta q_{i}^{(1)}\left\{\Phi_{i}^{(1)}\right\}+\Delta q_{i}^{(2)}\left\{\Phi_{i}^{(2)}\right\}+\cdots
$$

ここで $\Delta q_{i}^{(s)}$ は第 $s$ 次のモード変位増分を表し, 次式で定義される.

$$
\Delta q_{i}^{(s)}=\left\{\Phi^{(s)}\right\}^{T}[M]\left\{\Delta u_{i}\right\}
$$

次節では $\Delta \tau=0.01$ 秒とし, 図 7 に示すように, (1) 変位増分: $\left\{\Delta u_{i}\right\}$, （2）変位増分の 1 次モード成分： $\Delta q_{i}^{(1)}\left\{\phi_{i}^{(1)}\right\}$, (3) 変位増分の 2 次 モード成分： $\Delta q_{i}^{(2)}\left\{\phi_{i}^{(2)}\right\}$, (4) 変位増分の 1 次モード成分と 2 次モ 一ド成分の和 $\Delta q_{i}^{(1)}\left\{\phi_{i}^{(1)}\right\}+\Delta q_{i}^{(2)}\left\{\phi_{i}^{(2)}\right\}$ について比較検討を行う.

\section{2 .2 応答の分析}

本節では，逆三角形の初速度分布を与えた時の運動について分析 した結果を示す．本節では第二分枝勾配比 $\alpha=0$ の完全弾塑性とす る。なお，紙面の都合上割愛したが，本研究では一様分布の初速度 を与えた場合についても検討を行っており，既往の研究 ${ }^{3,4)}$ と同様 に, 初速度の分布が逆三角形分布と一様分布のどちらの場合でも, 最終的に同一の変形集中領域高さとなることを確認している.

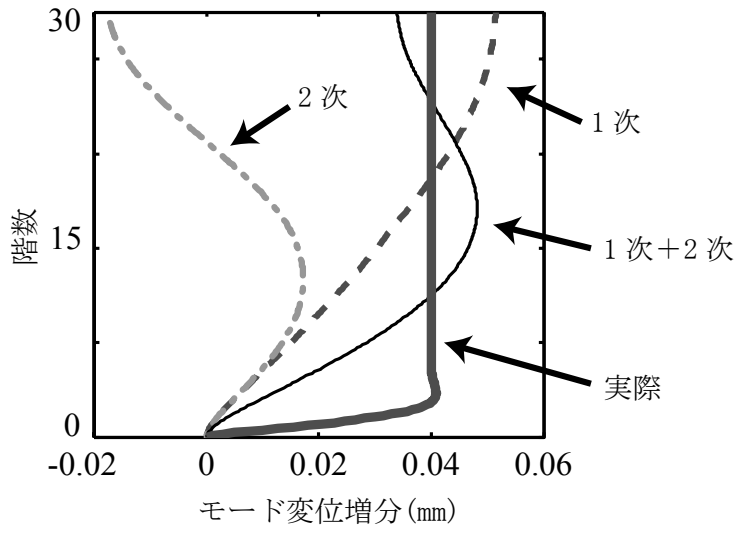

図 7 変位増分のモード分解 


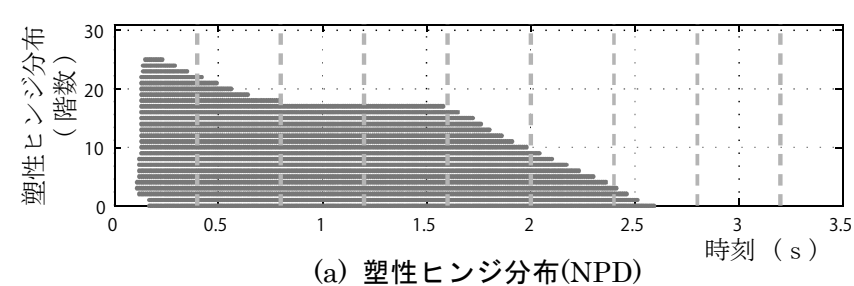

（a）塑性ヒンジ分布(NPD)

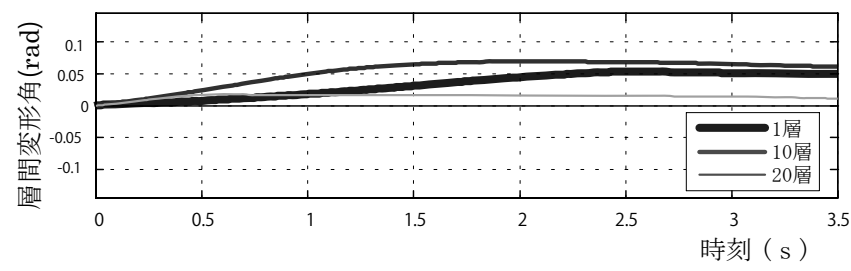

（c）時刻歴層間変形角 $(\mathrm{NPD})$
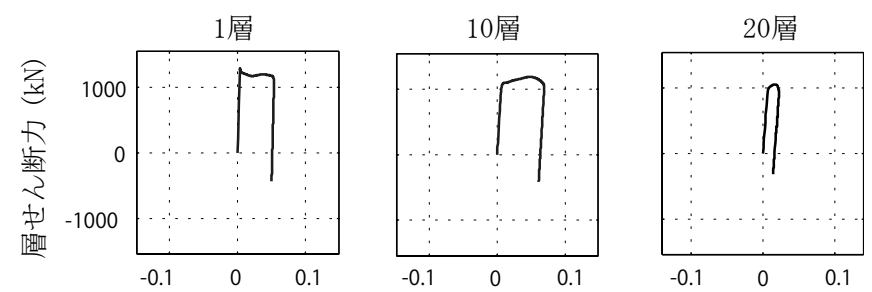

層間変形角 $(\mathrm{rad})$

(e) 層せん断力-層間変形角 (NPD)

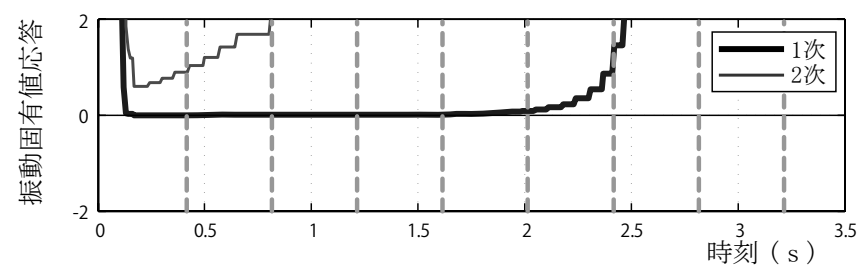

（g）時刻歴振動固有値(NPD)
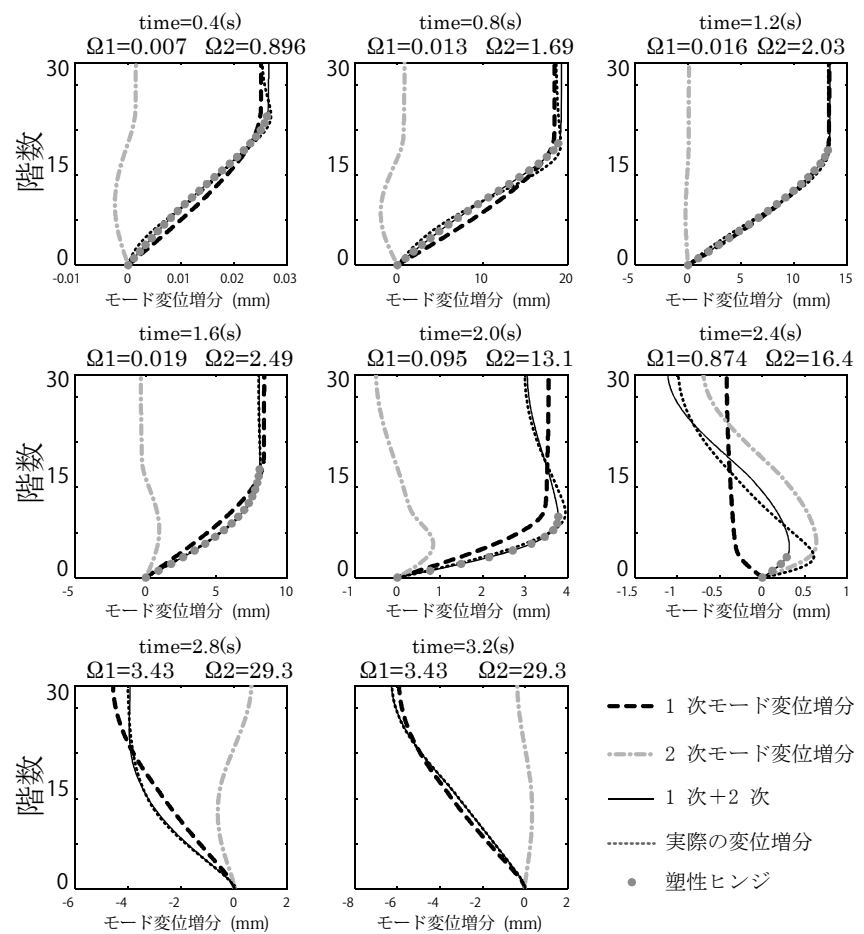

（i）瞬間増分に対するモーダルアナリシス(NPD)

--- 1 次モード変位増分

…- 2 次モード変位増分

- 1 次 +2 次

………実際の変位増分

・ 塑性ヒンジ

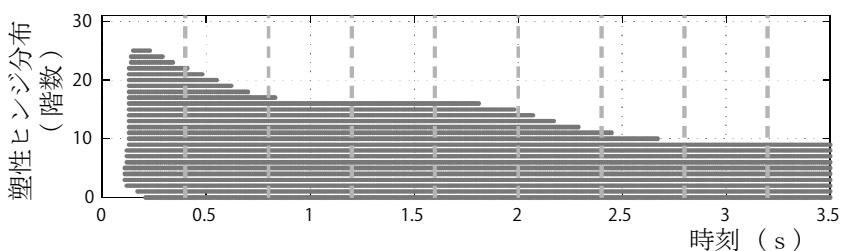

（b）塑性ヒンジ分布(PD)

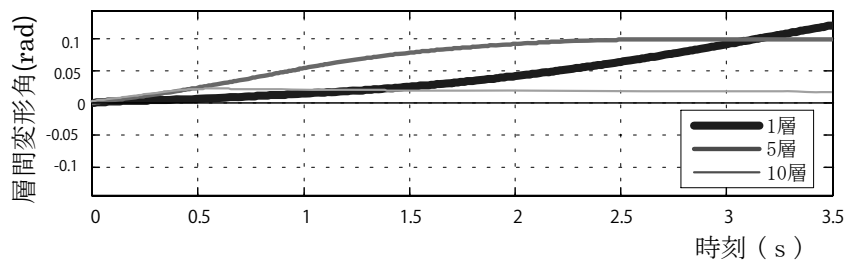

（d）時刻歴層間変形角 $(\mathrm{PD})$
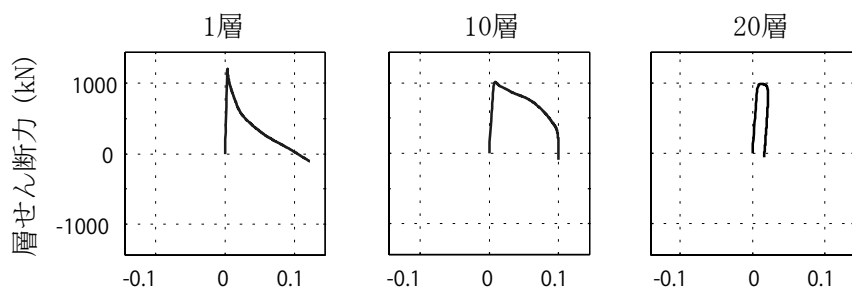

層間変形角 $(\mathrm{rad})$

(f) 層せん断力-層間変形角 $(\mathrm{PD})$

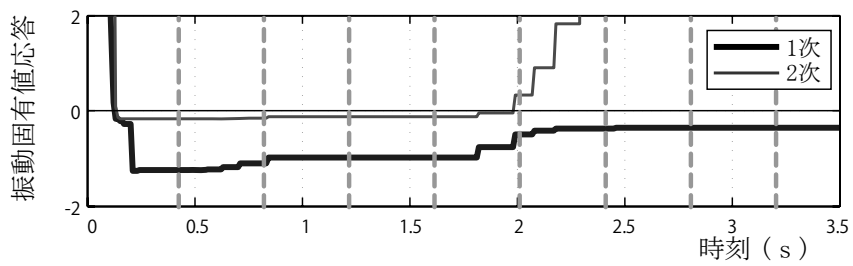

（h）時刻歴振動固有値(PD)
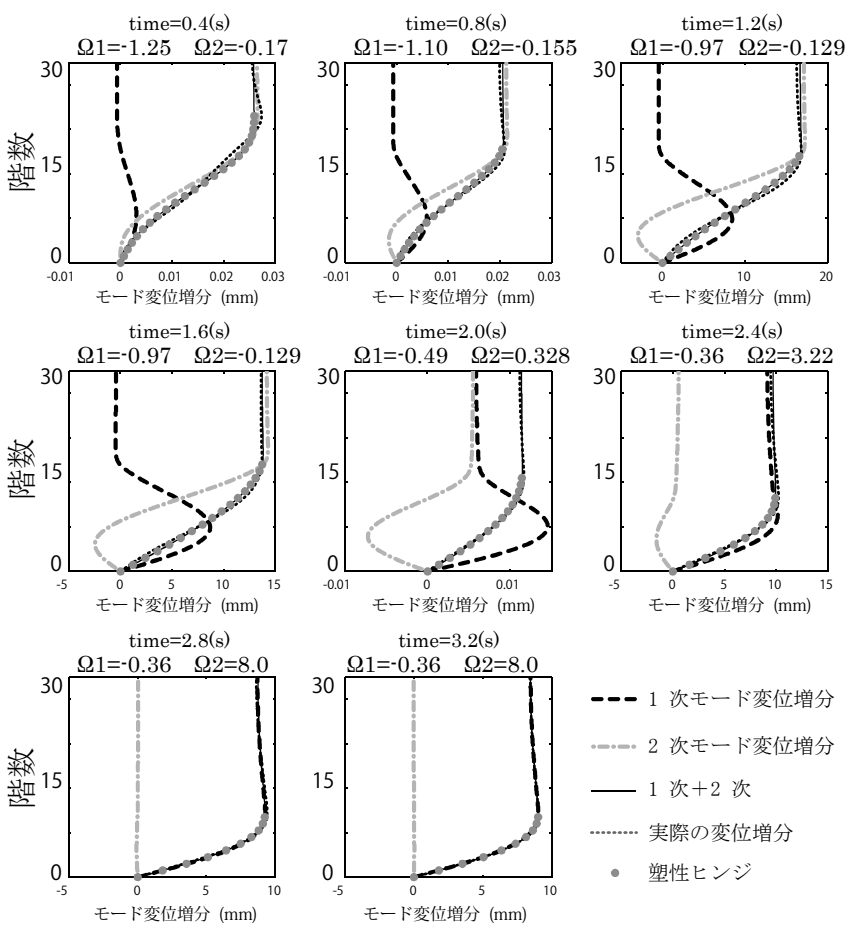

$\mathbf{- - - 1}$ 次モード変位增分

..--. 2 次モード変位增分

1 次 +2 次

………実際の変位増分

・ 塑性ヒンジ 
頂点の初速度を $400(\mathrm{~cm} / \mathrm{s})$ とした逆三角形分布の初速度を与えた 場合について解析結果を図 8 に示寸. 図 8 の左側は幾何非線形効果 を無視した場合（NPD: No P-Delta）の結果を，右側は幾何非線形効 果を考慮した場合 (PD: P-Delta) の結果を示寸. 各図からの観察結 果は以下の通りである。

1. 図 8(a), (b)は塑性ヒンジ分布の時間変化を示す. 横軸は時刻, 縦軸は塑性ヒンジが形成される梁が位置する層を示す，灰色の 丸が表示されている場合, 梁端に塑性ヒンジが形成されている ことを表す. NPD と PD ともに, 0.15 秒付近で 25 層程度までの 全層の梁端でほぼ同時に塑性ヒンジが形成され, その後上層か ら順に除荷していく. NPD では 2.5 秒付近で全塑性ヒンジが除 荷するのに対し, PD では 1９層の梁端が塑性化の状態を保っ たまま変形が進行する．これらの結果から，1～9 層が変形集中 領域であることが確認できる.

2. 図 8(c), (d)は代表層（1 層，10 層，20 層）における層間変形角 の時刻歴応答を示し, 図 8(e), (f)はこれらの層における層せん 断力と層間変形角の関係を示寸．NPD では 2.5 秒程度で除荷し た後, 再び降伏することはなく弾性振動する. PDでは2 秒以降, 1 層では変形が大きく進行しているのに対し, 10 層と 20 層では 変形が若干戻り除荷が生じる. また, 図 8(d),(f)より 3 秒付近で 第 1 層層せん断力が負荷の状態で 0 を通っており, その後は倒 壊に至る.

3. 図 $8(\mathrm{~g})$, (h)は振動固有值の時刻歴を示す. NPD の場合は図中で は 0.2 秒から 2 秒の間で振動固有值が 0 に近くなっているが, 図 8(i)の各グラフの上に示されているように最小固有值 $\Omega_{1}$ の数值 は常に正であることを確認している。一方, PDの場合は塑性化 領域が広がると $\Omega_{1}$ が負となり, その值は変動するものの塑性化 領域が一定となる約 2.5 秒以降は一定值をとっている.

4. 図 8(i), (j)は変位増分のモード分解の結果を示す. NPD と PD と もに，ほとんどの瞬間において 3 次以上の高次のモードの影響 は無視できるほど小さい．PD では, 1.8 秒までは 1 17 層の梁 が塑性化しており, 1 次と 2 次の振動固有值が近接するとともに どちらも負となり，2 次振動モードの影響が見られる．また， 1 次モードと 2 次モードの移り変わりと見られる現象も観察され る. しかし, 時間の経過とともに 1 次の振動モードが卓越し, 1 次振動モード折り返し点より上部の層の梁端の塑性ヒンジが除 荷する，その結果，変形集中領域は1９層で安定する.

以上の結果より， 3.2 節で述べた 1 次振動モード形状に着目した 下層部変形集中メカニズムは妥当であると考えられる.

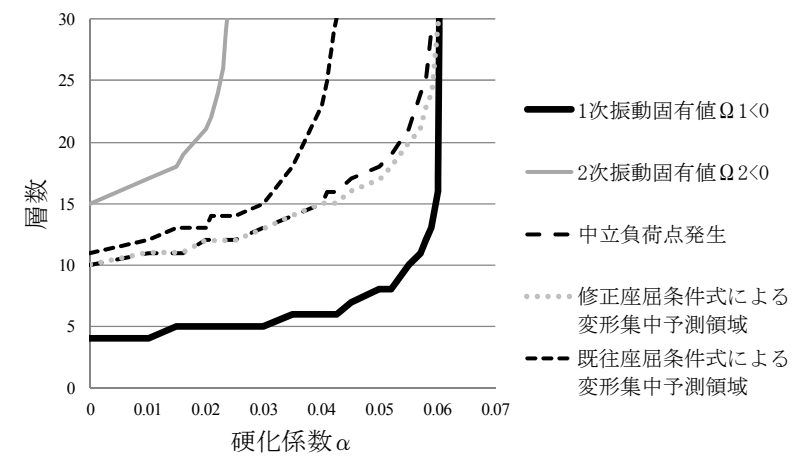

図 9 固有値解析の結果

\section{3 修正座屈条件式の検証}

\subsection{1 振動固有値解析結果との比較}

図 9 は第二分枝勾配比 $\alpha$ をパラメータとして変化させた時の, 変 形集中領域の変化を示寸。ここでは, 塑性化領域を下から順次高く しながら振動固有值解析を行い, 1 次振動モードに折り返し点（= 梁端塑性ヒンジが中立負荷となる点）が初めて発生した時の塑性化 領域を「中立負荷点高さ」と呼ぶ。比較のため, 4.1 節で述べた従 来及び修正座屈条件式により变形集中領域を予測した結果と, 塑性 化領域を下から順次高くする振動固有值解析で 1 次振動固有值 $\Omega_{1}$ が初めて負となる時と, 2 次振動固有值 $\Omega_{2}$ が初めて負となる時の塑 性化領域も示している. 図 9 より, 以下の事項が確認できる.

1. 修正座屈条件式が中立負荷点高さを精度よく予測している.

2. $\alpha$ の值が小さい時は従来座屈条件式と修正座屈条件式の間の差 は小さいが， $\alpha$ の值が大きくなるにつれて差異が大きくなる

3. $\alpha$ の值を大きくするにつれ変形集中領域は高くなる. 変形集中 領域が全層を超えると変形集中現象は発生しないと予測される。 図 9 より, 修正座屈条件式による変形集中の抑止条件は $\alpha>0.06$ である。また，本骨組では一方向へ変形が累積するドリフト現 象を抑止する条件（= $\Omega_{1}>0$ となる条件） ${ }^{4)}$ も $\alpha>0.06$ である.

\section{3 .2 既往座屈条件式との比較}

4.1 節の二つの座屈条件式による座屈荷重に差異が現れる原因を, 単純モデルの座屈解析を通して考察する.図 10 の 2 部材 3 節点単純 モデルに対し座屈固有值解析と静的増分解析を行う。部材のヤング 係数を $E$ ，断面 2 次モーメントを $I ，$ 骨組高さを $L$ とし，值はそ れぞれ $205.8\left(\mathrm{kN} / \mathrm{cm}^{2}\right) ， 3 \times 10^{5}\left(\mathrm{~cm}^{4}\right) ， 600(\mathrm{~cm})$ とする。中間荷重の ない時の Euler 座屈荷重は $\pi^{2} E I / L^{2}$ であり,この時 $1.69 \times 10^{3}(\mathrm{kN})$ とな る。節点と中間節点にかかる鉛直荷重の比率を $1: n$ とし, 座屈固有 值解析により求めた座屈荷重を $\Lambda_{c}$ とする．ここで $\Lambda_{c}$ は Euler 座屈 荷重により無次元化したものとする. 図11(a)は $n$ を変化させた時の $\Lambda_{c}$ の変化を示す. $n$ が増加するにつれ, 既往座屈条件と比べ修正座 屈条件は低い座屈荷重係数の值を与える. 図 11(b)は骨組にかかる総 荷重 $(1+n) \Lambda_{c}$ の変化を示す。既往座屈条件では $n$ の増加により $(1+n) \Lambda_{c}$ が増加しており, 修正座屈条件では $(1+n) \Lambda_{c}$ が減少してい る. 修正座屈条件において総荷重 $(1+n) \Lambda_{c}$ が $n$ の増加に伴い低下寸 る理由は, 修正座屈条件では中間節点に作用する鉛直荷重が変形モ 一ドの柱材軸直交方向（座屈を助長する方向）の成分を持ち，座屈 が起きや寸くなるためと考えられる. 図 9 において $\alpha$ の值が小さい 時は, 変形集中領域が低層のみで等価部分骨組の頂部節点にかかる 荷重に対し中間節点に作用する荷重の比率が低く, 既往と修正の座 屈条件式の差が小さい，一方， $\alpha$ の值が大きくなるにつれ中間荷重 の影響が大きくなり，これに伴い差も大きくなる．なお，中間荷重 がない $(n=0$ の $)$ 場合, 既往・修正の両座屈条件式が同じ座屈荷重 を与えることが数学的に証明できる(Appendix2).

静的増分解析による比較を行う. 図 10 の解析骨組に対し 4.1 節の 境界条件を満たしながら，変位制御による増分解析を行う。既往座 屈条件では中間節点 $x$ 方向变位が，修正座屈条件では頂点節点 $x$ 方 向変位が, どちらも $10^{-1} \times L$ となるまで増分解析を行う. 解析骨組の 初期不整は中間節点 $X$ 方向初期変位 $10^{-5} \times L$, 解析ステップ数は 5000 ステップ, 中間荷重係数は $n=1$ とする. 図 12 は増分解析の制 御変位と（無次元化）頂点節点鉛直荷重の関係を示寸．前節で求め 
た座屈固有值に近づくにつれ急激に变位が増加することが確認でき る. 図 13 に制御変位と頂点節点水平荷重の関係を示す. 既往座屈条 件では頂点節点に水平荷重はかからないが, 修正座屈条件では頂点 節点変位の増加に伴い水平荷重が負になっている.

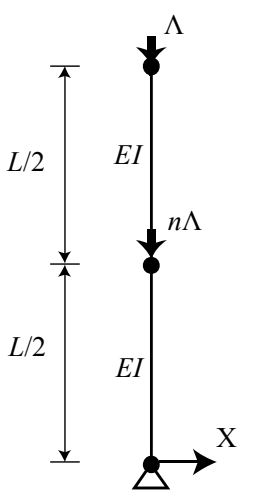

(a) 対象骨組

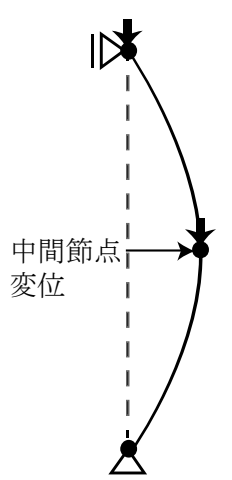

(b) 既往座屈条件 (c) 修正座屈条件 図 10 座屈解析モデル

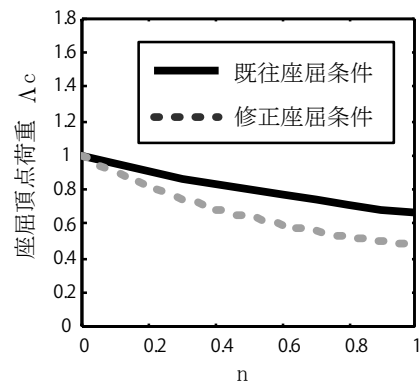

(a) 座屈頂点荷重の変化

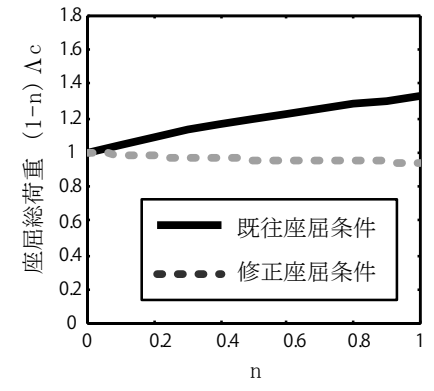

(b) 座屈総荷重の変化
図 11 中間荷重係数と座屈荷重の関係

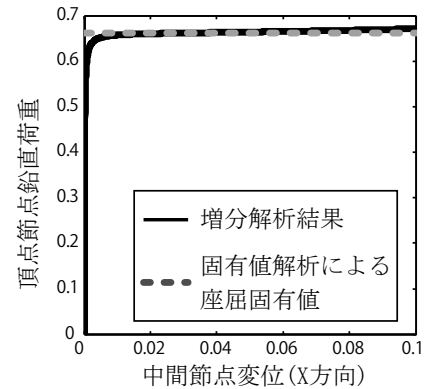

(a) 既往座屈条件

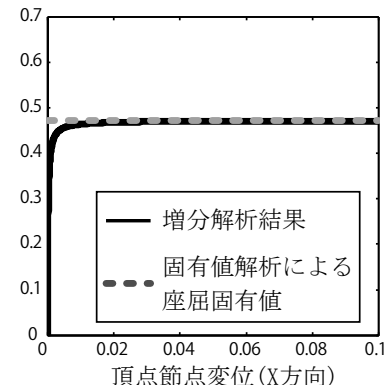

(b) 修正座屈条件
図 12 制御変位と頂点節点鉛直荷重の関係

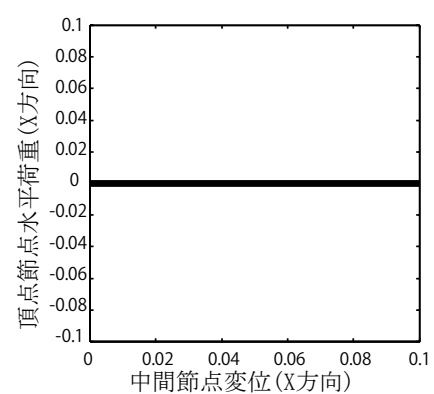

(a) 既往座屈条件

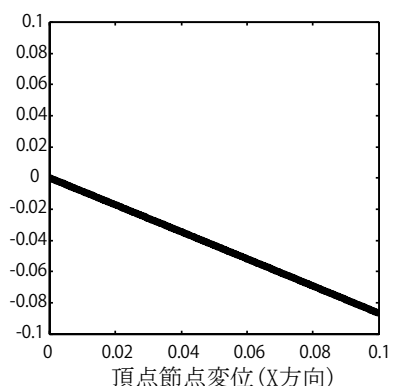

(b) 修正座屈条件

\subsection{3 周期地動に対する時刻歴応答解析結果との比較}

正弦波を入力地震動とする時刻歴応答解析を通して，修正座屈条 件式の妥当性を検証する。地動の周期は $3.5 \mathrm{~s}$, 最大地動加速度は $300 \mathrm{~cm} / \mathrm{s}^{2}$ ，継続時間は $150 \mathrm{~s}$ とする。従来座屈条件式による抑止条 件は $\alpha>0.0425$, 修正座屈条件式による抑止条件は $\alpha>0.06$ であるこ とを踏まえ， $\alpha=0.055,0.065$ の二通りの場合について時刻歴応答解 析を行う。それぞれの場合の解析結果を図 14,15 に示寸. 図 14 (a), (b)より下層部において一方向に変形が発散的に増大していること がわかる。これに対し抑止条件を満たす場合は図 15 (a)，(b)より一 方向に変形が偏ることなく, 安定した振動応答を示す。これらの結 果より，修正座屈条件式に基づく抑止条件は妥当であるといえる.

\section{4 有限変形と柱塑性化の影響の検討}

前節までの解析は，有限変形（変形に応じて釣合式や適合条件式 が変化すること）の影響が小さいと考えられる変形領域（最大層間 変形角<0.1）を対象として，これらの影響を無視した解析を実施し た。また，下層部変形集中メカニズムの検討を明快に

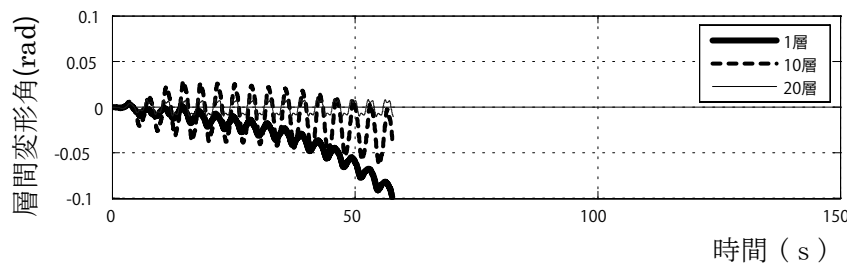

（a）時刻歴層間変形角 $(\mathrm{PD})$

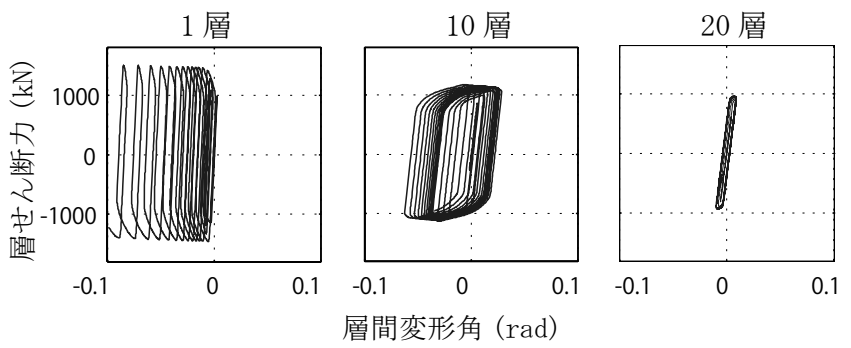

(b) 層せん断力-層間変形角 $(\mathrm{PD})$

図 $14 \alpha=0.055$ の場合の応答

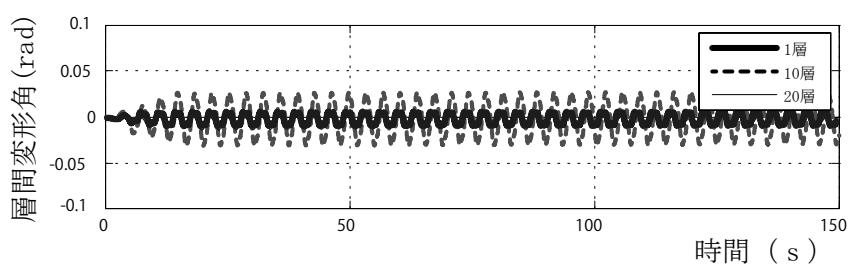

(a) 時刻歴層間変形角 (PD)
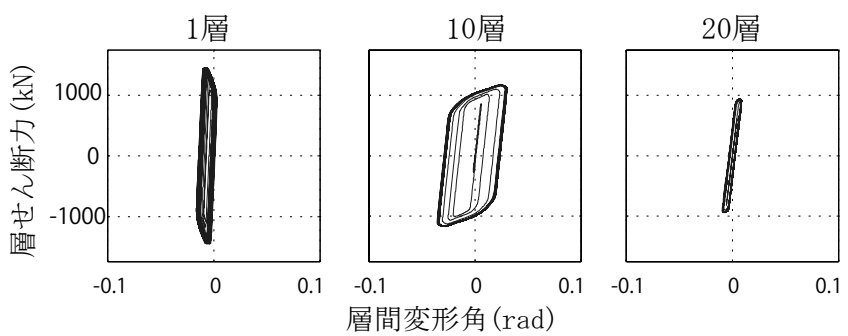

(b) 層せん断力-層間変形角 $(P D)$

図 $15 \alpha=0.065$ の場合の応答 
行うため, 第 1 層柱脚以外で柱には塑性ヒンジが発生しないとの仮 定のもとで解析を行った。本節では, 有限変形と第 1 層柱脚以外の 塑性化を考慮した場合との比較を行う。比較には, CLAP ${ }^{18)}$ を用い る. CLAP では移動座標系を用いることで, 有限変形の効果を厳密

表 2 解析一覧

\begin{tabular}{|c|c|c|c|}
\hline & 本報 & $\begin{array}{c}\text { CLAP } \\
(1 \text { 層柱脚のみ弾塑性) }\end{array}$ & $\begin{array}{c}\text { CLAP } \\
\text { (全層柱弾塑性) }\end{array}$ \\
\hline 有限回転 & $\times$ & 0 & 0 \\
\hline 柱弾塑性 & 1 層柱脚のみ & 1 層柱脚のみ & 全層 \\
\hline \multirow{3}{*}{ 解析結果 } & 図 16 & & \\
\hline & \multicolumn{2}{|r|}{ 図 17} & \\
\hline & & \multicolumn{2}{|c|}{ 図 $18,19,20$} \\
\hline
\end{tabular}

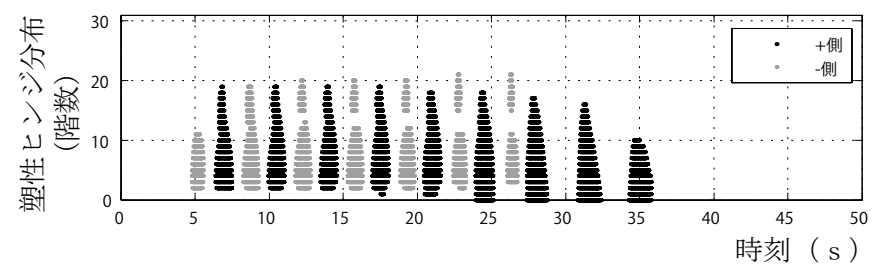

（a）塑性ヒンジ分布 (PD)

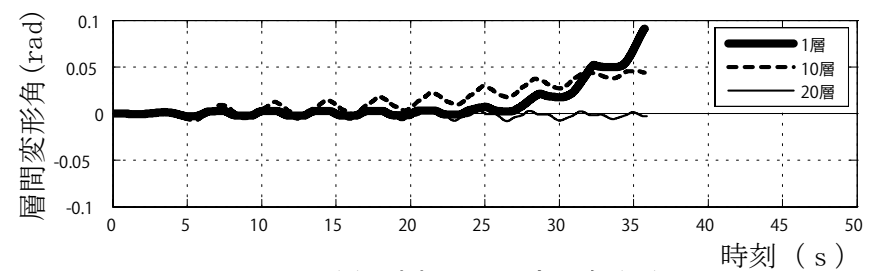

(b) 時刻歴層間変形角 $(\mathrm{PD})$
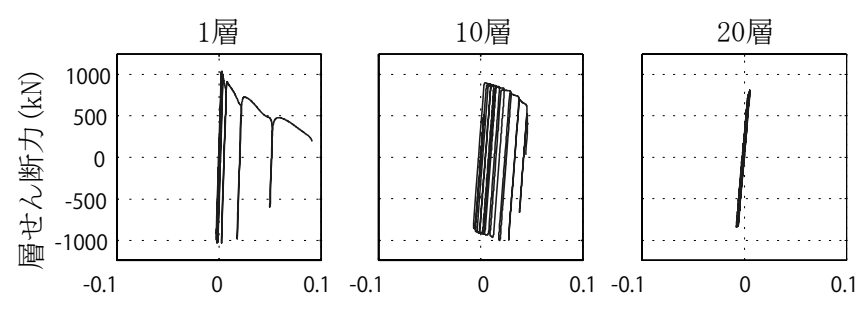

層間変形角 $(\mathrm{rad})$

(c) 層せん断力-層間変形角 $(\mathrm{PD})$
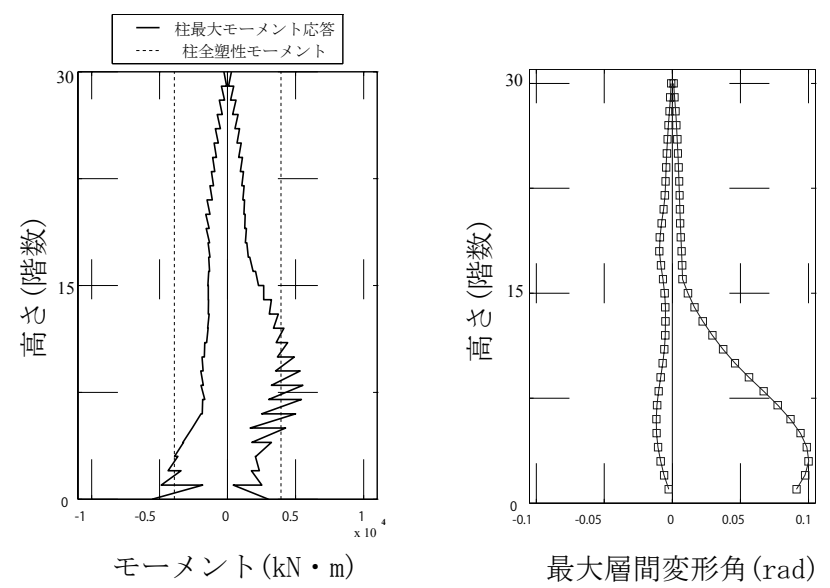

(d) 柱最大モーメント $(P D)$

(e) 最大層間変形角 $(P D)$

図 16 本報解析プログラム応答

に扱っている．また，柱の塑性化を部材両端に配置した一般化塑性 ヒンジにより表現している. 入力地震動は正弦波とし, 周期 $3.5 \mathrm{~s}$, 最大地動加速度 $50 \mathrm{~cm} / \mathrm{s}^{2}$, 継続時間 $50 \mathrm{~s}$ とする. また構成則は柱と梁 はともに完全弾塑性とする。本節の解析一覧を表 2 に示す.

まず，有限回転及び 1 層柱脚を除く柱の塑性化を考慮しない場合 の解析結果を図 16 に示寸. 解析打ち切り層間変形角を $0.1 \mathrm{rad}$ とし た. 図 16(a)，(b)，(e)より 5.2 節と同様に下層部にのみ塑性ヒンジ分 布が集中し, 変形が増大していることが確認できる.また, 図 16 (c), (d)より, まだ層せん断力が 0 となる前に, 柱の最大モーメントは 1 層柱脚のみならず, 2 層と 6〜10 層で全塑性モーメントに達してい ることが観察できる.

また, CLAP により有限変形を考慮した解析（柱の塑性化は第 1 層柱脚に限定）を行い，上記の結果との比較を行う。変形が大きい 下層部の 1 層, 10 層, 20 層における時刻歴層間変形角を比較したも のを図 17 に示す.これより, 変形が最も大きい 1 層層間変形角にお いて $0.2 \mathrm{rad}$ 程度まで応答が概ね一致していることがわかる.

さらに, CLAPにより柱塑性化と有限変形を考慮した解析を行い, 第 1 層柱脚以外の柱の塑性化を無視した（有限変形は考慮）した解 析結果との比較を行う. 図 18 に下層部の時刻歷層間変形角をそれぞ れに場合について示す，これより 30 秒付近より応答が違ってくる. 図 19 に 35 秒付近で初めて 6-8 層柱頭に塑性ヒンジが発生した時の 塑性ヒンジ図を示す, これより崩壊機構が変化し，そのため図 20 の最大層間変形角の比較が示すように，より低層部で変形が集中す る. なお, 下層部変形集中現象の発生に伴う変形集中高さ以下への 崩壊機構の変化は文献 15)にも報告されている.
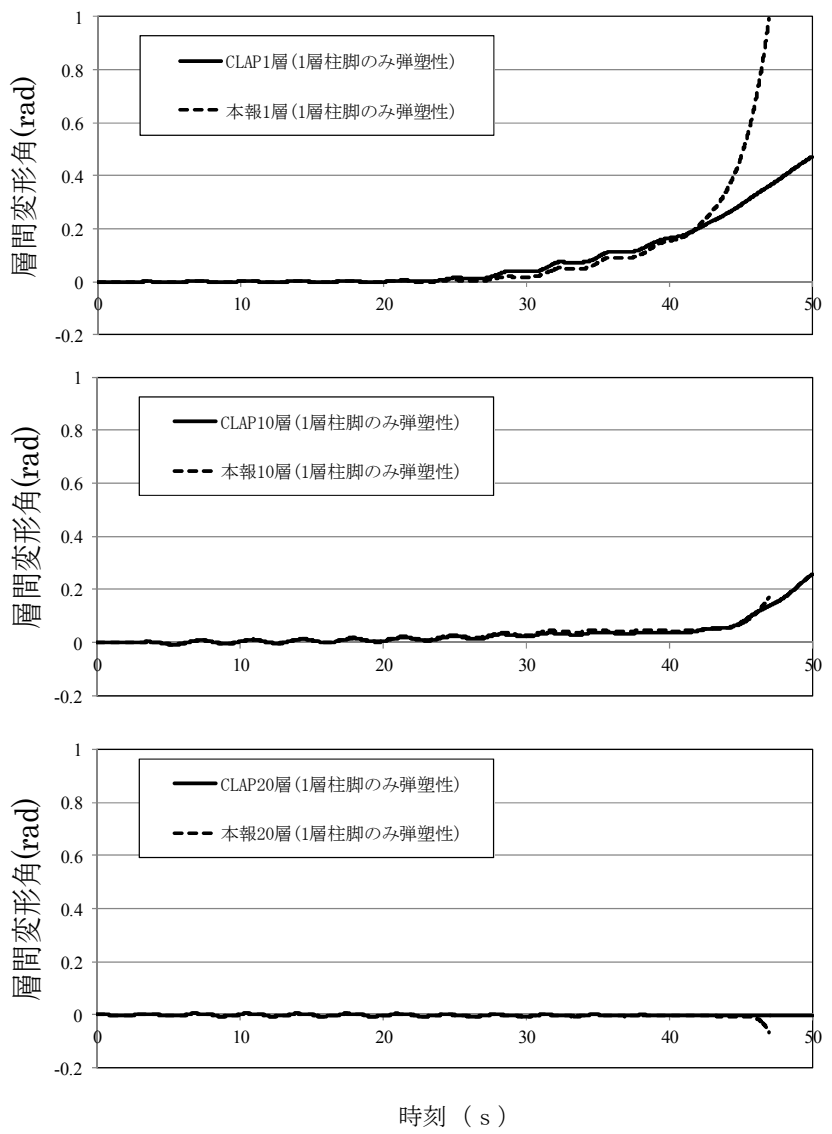

図 17 有限回転考慮時との比較 

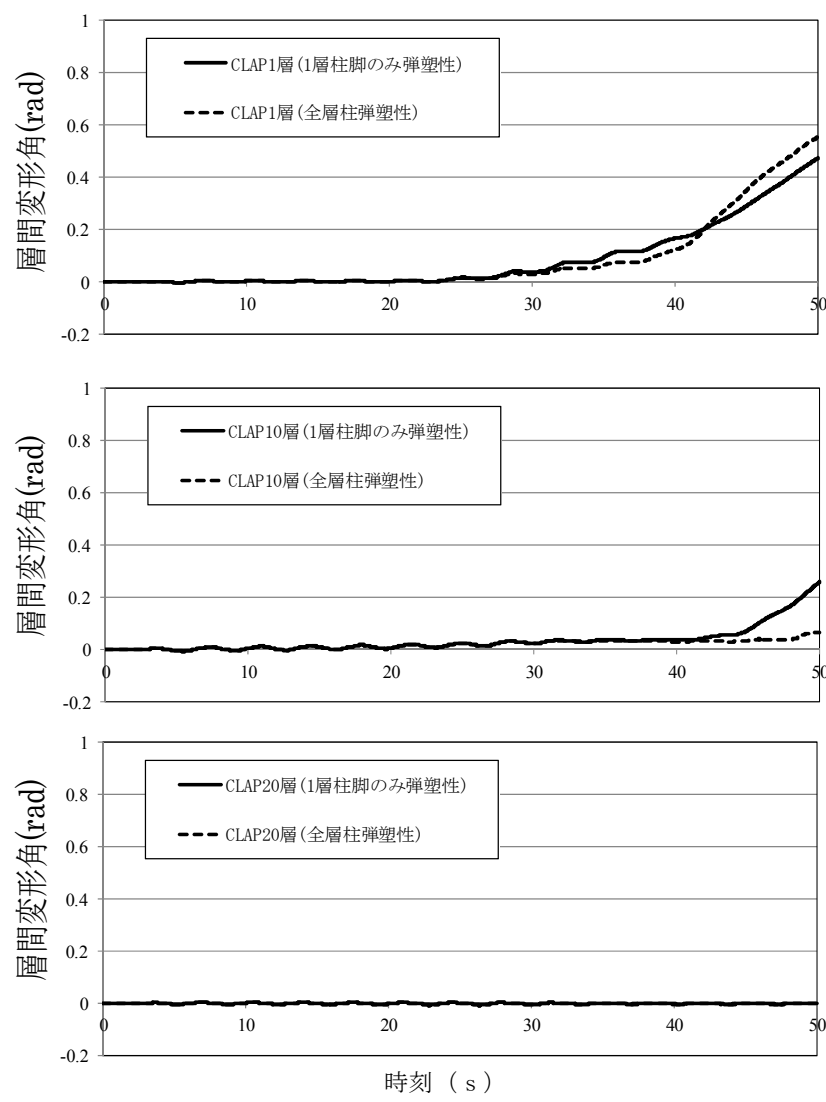

図 18 全層柱弾塑性考慮時との比較

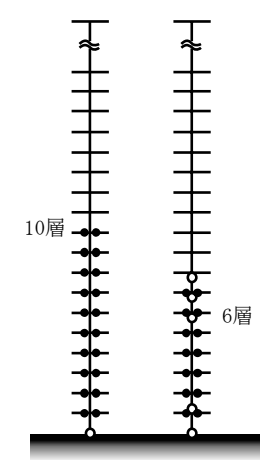

(a) 1 層柱脚のみ $\quad$ (b) 全層

図 19 崩壊形比較

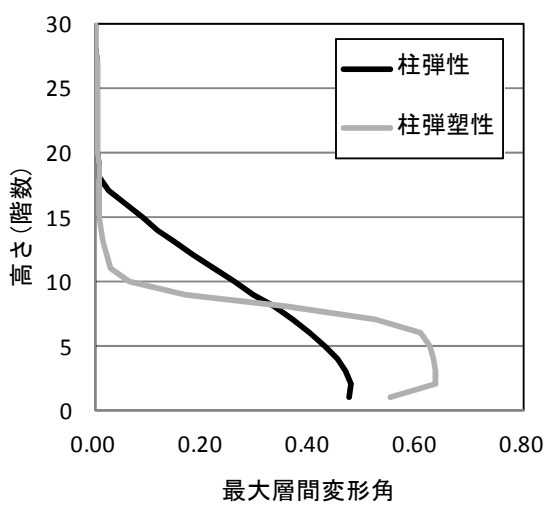

図 20 最大層間変形比較

\section{6. 結}

本論文では以下の結論を得た。

1. 以下の下層部変形集中メカニズムを提示した。「幾何非線形を考 慮した場合, 接線剛性行列を用いた振動固有值解析で得られる 振動固有モードにおいて, 梁端の塑性ヒンジが中立負荷となる 高さには上限がある．塑性化領域がこの上限を超えると，上限 より上の層では除荷が生じる. そのため, 上限よりも下層部に 塑性化領域と変形集中領域が限定される. このことが下層部に 変形が集中するメカニズムである.」また, 塑性化領域を 1 層か ら順次増加させた振動固有值解析と, 初期速度に対する応答の 時刻歴応答解析を通して, 提案メカニズムの妥当性を例証した.

2. 提案メカニズムに基づき, 変形集中領域を予測するための修正 座屈条件式を提示した。既往座屈条件式では変形集中領域頂部
の水平変位を拘束していたのに対し, 修正座屈条件式では頂部 の回転角を拘束している点が特徵である。この修正は，頂部の 梁端塑性ヒンジが中立負荷となっていることに対応する．座屈 固有值解析により, 中間荷重を考慮した場合, 修正座屈条件式 では既往座屈条件式より低い座屈荷重係数を与えることを例示 するとともに, 振動固有值解析と周期地動に対寸る時刻歴応答 解析結果との比較により, 修正座屈条件式の妥当性を例示した.

3. 本論文で検討した骨組では, 最大層間変形角が 0.15 程度までは, 有限変形の考慮の有無が応答に及ぼす影響が小さいことを確認 した．また，有限変形を無視した方が最大変形を大きめに予測 する（設計の観点から見ると安全側の予測となる）ことを確認 した．また，柱の塑性化の考慮の有無の比較を通して，下層部 変形集中現象が発生すると以下のプロセスで倒壊に至ることを 例示した。（1）下層部変形集中現象が発生すると変形集中領域 においてオイラー座屈時と同様の分布を持つ弓型の付加曲げモ ーメント増分が柱に発生する.（2）付加曲げモーメント増分が 最大となる変形集中領域のほぼ中央の高さの位置で塑性ヒンジ が柱に生じる。（3）変形集中領域のほぼ半分程度の高さの領域 で崩壊機構を形成し倒壊に至る。

\section{謝辞}

本研究は科学研究費補助金基盤研究(B) No. 23360245 の助成の下 で実施した，平面骨組解析プログラム CLAP は大阪大学の多田元英 先生から提供を受けた。ここに記して謝意を表する.

\section{参考文献}

1) 日本建築学会：長周期地震動と建築物の耐震性，2007.

2）日本建築学会 : 大振幅地震動と建築物の耐震性一巨大海溝型地震 ・内陸 地震に備えて一, 2013.

3) 上谷宏二, 田川浩: 梁降伏型骨組の動的崩壊過程における変形集中現象, 日本建築学会構造系論文集，第 483 号，pp.51-60，1996.5

4) K Uetani, H Tagawa: Criteria for suppression of deformation concentration of building frames under severe earthquakes, Engineering Structures, Vol. 20, Nos 4-6, pp. 372-383, 1998

5）金紋廷，荒木慶一，山川誠，田川浩，五十子幸樹：極大地震動に対する 純ラーメン超高層鋼構造骨組の動的応答に及ぼす $P$ - $\Delta$ 効果の影響, 日本 建築学会構造系論文集，第 644 号，pp. 1861-1868，2009.10

6）荒木慶一，金紋廷，西本篤史，五十子幸樹，上谷宏二：長周期地震動を 受ける座屈拘束ブレース付超高層鋼構造骨組における下層部変形集中現 象, 日本建築学会構造系論文集, 第 78 巻, 第 686 号, pp. 743-752, 2013.4

7) 上谷宏二, 田川浩 : 梁降伏型多層多スパン平面骨組みの動的崩壊挙動解 析, 日本建築学会近畿支部研究報告集, pp.245-252, 平成 6 年度

8) W McGuire, RH Gallagher, RD Ziemian: Matrix Structural Analysis, Wiley, 1999.

9) PC Jennings, R Husid: Collapse of yielding structures during earthquakes, Journal of Engineering Mechanics Div. ASCE, Vol. 99(EM5), pp. 1045-1065, 1968.

10) ZP Bazant, M Jirasek: Softening-induced dynamic localization instability: seismic damage in frames, Journal of Engineering Mechanics ASCE, Vol. 122, pp. 1149-1158, 1996.

11) D Bernal: Instability of buildings during seismic response, Engineering Structures, Vol. 20, pp. 496-502, 1998.

12）上谷宏二: 繰返し水平載荷を受ける多層多スパン平面骨組の塑性崩壊挙 動，その 1, 日本建築学会構造系論文報告集，第 435 号，pp. 61-70, 1992.5 
13）上谷宏二, 東海幸一, 中村恒善: 繰返し水平載荷を受ける多層多スパン 平面骨組の塑性崩壊挙動, その 2 , 日本建築学会構造系論文報告集, 第 454 号, pp. 73-83, 1993.12

14）上谷宏二, 田川浩：一方向頂点水平変位を受ける多層平面骨組みモデル の分岐挙動解析, 日本建築学会構造系論文報告集, 第 453 号, pp. 101-110, 1993.11

15）上谷宏二, 東海幸一, 森迫清貴, 石田修三 : 周期地動を受ける梁降伏型 平面骨組みの動的崩壊, 日本建築学会構造系論文集, 第 474 号, pp. 87-95, 1995.

16）上谷宏二, 田川浩：繰返し頂点水平変位を受ける多層平面骨組の弾塑性 分岐挙動，構造工学論文集，41B，pp. 631-636，1995.8

17) JC Simo, TJR Hughes: Computational Inelasticity, Springer, 1998.

18）小川厚治, 多田元英 : 柱・梁接合部パネルの変形を考慮した静的・動的 応答解析プログラムの開発, 第 17 回情報・システム・利用・技術シンポ ジウム論文集，pp. 79-84，1994.

\section{Appendix1：座屈固有值解析での境界条件の扱い}

4.1 節において座屈固有值解析を行うにあたり, 外力ベクトル $\{f\}$ と変位べ クトル $\{u\}$ の剛性方程式は材料接線剖性行列 $\left[K_{m t}\right]$ と幾何剛性行列 $\left[K_{g}\right]$ と荷 重係数 $\Lambda$ を用いて

$$
\{f\}=\left(\left[K_{m t}\right]-\Lambda\left[K_{g}\right]\right)\{u\}
$$

となる．解析対象とする $0-j$ 層部分骨組では式(11)は

$\left\{\begin{array}{c}H_{0} \\ V_{0} \\ M_{0} \\ \hline \vdots \\ \hline H_{j} \\ V_{j} \\ M_{j}\end{array}\right\}=\left[\begin{array}{ccc|c|ccc}k_{11} & k_{12} & k_{13} & & k_{1(3 j-2)} & k_{1(3 j-1)} & k_{1(3 j)} \\ k_{21} & k_{22} & k_{23} & \cdots & k_{2(3 j-2)} & k_{2(3 j-1)} & k_{2(3 j)} \\ k_{31} & k_{32} & k_{33} & & k_{3(3 j-2)} & k_{3(3 j-1)} & k_{3(3 j)} \\ \hdashline & \vdots & & \ddots & & \vdots & \\ \hline k_{(3 j-2) 1} & k_{(3 j-2) 2} & k_{(3 j-2) 3} & & k_{(3 j-2)(3 j-2)} & k_{(3 j-2)(3 j-1)} & k_{(3 j-2)(3 j)} \\ k_{(3 j-1) 1} & k_{(3 j-1) 2} & k_{(3 j-1) 3} & \cdots & k_{(3 j-1)(3 j-2)} & k_{(3 j-1)(3 j-1)} & k_{(3 j-1)(3)} \\ k_{(3 j) 1} & k_{(3 j) 2} & k_{(3 j) 3} & & k_{(3 j)(3 j-2)} & k_{(3 j)(3 j-1)} & k_{(3 j)(3 j)}\end{array}\right]\left\{\begin{array}{c}u_{0} \\ v_{0} \\ \theta_{0} \\ \vdots \vdots \\ \hdashline u_{j} \\ v_{j} \\ \theta_{j}\end{array}\right\}$

となる. ここで $H_{l}, V_{l}, M_{l}$ は $l$ 層節点にかかる水平外力, 鉛直外力, 外力モー メントであり， $u_{l}, v_{l}, \theta_{l}$ は $l$ 層節点の水平変位, 鉛直変位, 回転角である. ま た $k_{x y}$ は剛性行列 $\left(\left[K_{m t}\right]-\Lambda\left[K_{g}\right]\right)$ の $x$ 行 $y$ 列成分である. 上式で境界条件を考 慮する際に, 既知の外力 $\{\bar{f}\}$ と末知の変位 $\{\hat{u}\}$ の関係式としなければならな い. 修正座屈条件式では $\left(H_{0}, V_{0}, H_{j}\right)$ が未知であり $\left(u_{0}, v_{0}, \theta_{j}\right)$ が既知となる, $\left(H_{0}, V_{0}\right)$ と $\left(u_{0}, v_{0}\right)$ では行が対応しているが， $H_{0}$ と $\theta_{j}$ は行が対応していない ため剛性行列の $(3 j-2)$ 行要素と $(3 j)$ 行要素を入れ替え以下のようにする

$\left\{\begin{array}{c}H_{0} \\ V_{0} \\ M_{0} \\ \hline \vdots \\ \hline M_{j} \\ V_{j} \\ H_{j}\end{array}\right\}=\left[\begin{array}{ccc|c|ccc}k_{11} & k_{12} & k_{13} & & k_{1(3 j-2)} & k_{1(3 j-1)} & k_{1(3 j)} \\ k_{21} & k_{22} & k_{23} & \cdots & k_{2(3 j-2)} & k_{2(3 j-1)} & k_{2(3 j)} \\ k_{31} & k_{32} & k_{33} & & k_{3(3 j-2)} & k_{3(3 j-1)} & k_{3(3 j)} \\ \hdashline & \vdots & & \ddots & & \vdots & \\ \hdashline k_{(3 j) 1} & k_{(3 j) 2} & k_{(3 j) 3} & & k_{(3 j)(3 j-2)} & k_{(3 j)(3 j-1)} & k_{(3 j)(3 j)} \\ k_{(3 j-1) 1} & k_{(3 j-1) 2} & k_{(3 j-1) 3} & \cdots & k_{(3 j-1)(3 j-2)} & k_{(3 j-1)(3 j-1)} & k_{(3 j-1)(3 j)} \\ k_{(3 j-2) 1} & k_{(3 j-2) 2} & k_{(3 j-2) 3} & & k_{(3 j-2)(3 j-2)} & k_{(3 j-2)(3 j-1)} & k_{(3 j-2)(3 j)}\end{array}\right]\left\{\begin{array}{c}u_{0} \\ v_{0} \\ \theta_{0} \\ \vdots \\ \hdashline u_{j} \\ v_{j} \\ \theta_{j}\end{array}\right\}$

$\left(H_{0}, V_{0}, H_{j}\right)$ 及び $\left(u_{0}, v_{0}, \theta_{j}\right)$ に対応した剛性行列の 1 行要素, 1 列要素, 2 行 要素, 2 列要素及び $(3 j)$ 行要素, $(3 j)$ 列要素を消去する, この時, 既知の 外力ベクトルと未知の変位ベクトルの関係式は以下のようにかける.

$\{\bar{f}\}=\left(\left[\tilde{K}_{m t}\right]-\Lambda\left[\tilde{K}_{g}\right]\right)\{\hat{u}\} \Leftrightarrow\left\{\begin{array}{c}M_{0} \\ \hdashline \vdots \\ \hdashline M_{j} \\ V_{j}\end{array}\right\}=\left[\begin{array}{c:c:cc}k_{33} & \cdots & k_{3(3 j-2)} & k_{3(3 j-1)} \\ \hdashline \vdots & \ddots & \vdots & \vdots \\ \hdashline k_{(3 j) 3} & \cdots & k_{(3 j)(3 j-2)} & k_{(3, j)(3 j-1)} \\ k_{(3 j-1)} & & k_{(3 j-1)(3 j-2)} & k_{(3 j-1)(3 j-1)}\end{array}\right]\left\{\begin{array}{c}\theta_{0} \\ \hdashline \vdots \\ \hdashline u_{j} \\ v_{j}\end{array}\right\}$

この剛性行列 $\left(\left[\tilde{K}_{m t}\right]-\Lambda\left[\tilde{K}_{g}\right]\right)$ を用いて式(7)の座屈固有值解析を行う.

Appendix2 : 中間荷重がない場合の座屈荷重及び座屈モード

4.1 節の二つの座屈条件式を満たす座屈荷重及び座屈モードを, 座屈たわみ
角法を用いて求める. 図 21 (a) に示す, 長さ $L$, ヤング係数 $E$, 断面 2 次モ一 メント $I$, 軸力 $N$ の柱 1 部材において, たわみ関数 $v(x)$ の一般解は定数 $C_{114}$ を用いて以下のように表わされる。

$$
v(x)=C_{1} \sin k x+C_{2} \cos k x+C_{3} x+C_{4}, \quad(k=\sqrt{N / E I})
$$

既往座屈条件の境界条件は

$$
v(0)=v(L)=0, d^{2} v / d x^{2}(0)=d^{2} v / d x^{2}(L)=0
$$

であるから座屈荷重 $\Lambda_{1}(=N)$ と座屈モード $v_{1}(x)$ は次式となる

$$
\Lambda_{1}=\pi^{2} E I / L^{2} \quad v_{1}(x)=C_{1} \sin k x
$$

同様に，修正座屈条件の境界条件は

$$
v(0)=v(L)=0, d^{2} v / d x^{2}(0)=0, d^{1} v / d x^{1}(L)=0
$$

であるから

$$
C_{2}=C_{4}=0, C_{1} \sin k L=0, k C_{1} \cos k L+C_{3}=0
$$

となり，非零のたわみが存在するための条件は次式になる

$$
\sin k L=0
$$

上式を満たす正の最小の $k$ は $k=\pi / L$ でありこの時座屈荷重 $\Lambda_{2}(=N)$ は

$$
\Lambda_{2}=\pi^{2} E I / L^{2}
$$

となり既往座屈条件による座屈荷重 $\Lambda_{1}$ と一致する。 また，修正座屈条件によ る座屈モード $v_{2}(x)$ は式(15),(22),(23)より

$$
v_{2}(x)=C_{3}(\sin k x+k x)
$$

となり，これらの座屈モードは図 21(b)，(c)のように表わされる。

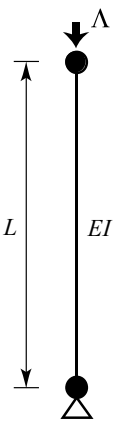

(a) 対象骨組

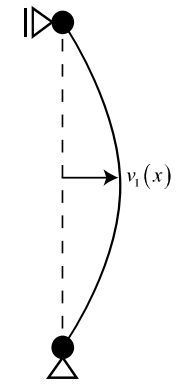

(b) 既往座屈条件

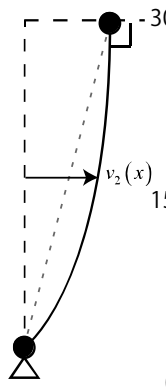

(c) 修正座屈条件

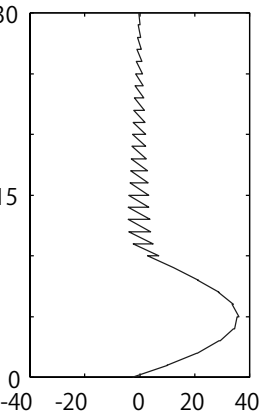

図 21 柱 1 部材での座屈モードの比較

\section{注}

注1）部分骨組最上層柱頭節点でモーメント $=0$ としているのは, 変形が大き く進む時は変形集中領域よりも上部でモーメント増分が 0 となること を反映している．下層部変形集中現象発生時のモーメント増分の具体 例として, 図 8(b)の 3.2 秒での柱モーメント増分を図 22 に示す. 変形 集中領域は 0-10 層であり, 10 層柱頭モーメント増分はほぼ 0 となって いる．座屈条件はこのモーメント増分の分布を反映している.

注2) 図 3(b)右は 1 次固有モードであって, 1 次のみならず高次モードを全て 重叔合わせて表される増分挙動ではない点に注意を要する．図 3(b)右 だけ見れば，折り返し点を境に 0-10 層の塑性ヒンジが負荷方向に回転 しており，11-15 層までは除荷方向に回転している，一方，増分挙動で は 0-15 層の塑性ヒンジは全て負荷方向に回転している.負の振動固有 值を持つ 1 次モードは指数関数的に増大寸るのに対し, 正の振動固有 值を持つ高次モードは三角関数的に振動する. そのため 1 次モードが 高次モードを凌駕して大きく成長していき，その過程で塑性ヒンジが 15 層から下層に向かって順次除荷される。除荷は変形集中領域の上限 である第 10 層で止まる．塑性化領域が 0-10 層と設定したときの 1 次 モードを示したのが図 3(b)中である. 1 次モード折り返し点は 10 層付 近にあり, 塑性化領域と一致する. 参考として図 8(j) の time $=2.8,3.2 \mathrm{sec}$ の図に着目寸れば, 2 次モードが殆どゼロにまで縮退しており，実際の 増分挙動は殆ど 1 次モードだけで占められていることが分かる. 


\title{
EXAMINING MECHANISMS BEHIND DEFORMATION CONCENTRATION INTO LOWER STORIES BASED ON MODAL DECOMPOSITION USING TANGENT STIFFNESS MATRIX
}

\author{
Yosuke MISAKI*, Shinnosuke OKAYAMA**, Yoshikazu ARAKI*** \\ and Koji UETANI****

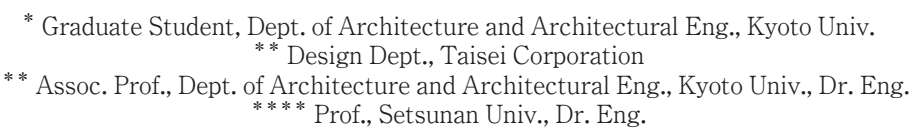

Uetani and Tagawa $(1996,1998)$ pointed out a new type of dynamic instability, called deformation concentration phenomena, wherein deformation concentrates in lower several stories when high-rise buildings are subjected to intense ground motions. Based on static stability theory, they proposed criteria for predicting the height of deformation concentration region. This paper examines the mechanisms behind the deformation concentration into lower stories of a building frame based on modal decomposition of displacement increment using the tangent stiffness matrix. An improved criterion is proposed for predicting the height of the deformation concentration region based on the presented mechanism. Furthermore, this paper studies the influence of large rotation and column yielding on dynamic collapse, which were neglected in the above examination of deformation concentration mechanism.

In Section 2, an analytical model is explained. The 30 story frame model is designed based on the strong-column-weak-beam concept as shown in Figure 1 and Table 1.

In Section 3, the mechanism of deformation concentration phenomena is scrutinized. To examine the mechanism of the deformation concentration phenomena, modal decomposition of displacement increment is performed using the tangent stiffness matrix, wherein both material and geometric nonlinearities are taken into account. The plastic region is increased from the $1 \mathrm{st}$ story one by one, and each time eigenvalue analysis is performed using each tangent stiffness matrix. Examples of the results are shown in Figure 3 . When the plastic region increases at a certain height, unloading takes place in upper portion of the plastic region as shown in Figure 3(b), which prohibits plastic region to increase above the point. This is the mechanism for the deformation concentration phenomena.

In Section 4, we propose a modified criterion for predicting the height of the deformation concentration region. In the previous studies, the deformation concentration region was predicted as the height of an equivalent frame at which it buckles by its self-weight. The equivalent frame was defined using the tangent stiffness of plastic hinges. The boundary condition of the column of the equivalent frame was given as simple support. We propose a modified boundary condition, wherein both the horizontal displacement and the rotation angle are constrained at the top of the column. This boundary condition corresponds to the fact that at the top of the deformation concentration region, neutral loading takes place at the beam ends while moment becomes zero at the top column end.

In Section 5, time history response analyses are performed to examine the validity of the proposed mechanism and the improved criterion. First, time history analysis of free vibration under initial velocity is performed in Section 5.2. In Figure 8(j), modal decomposition of displacement increment is shown. In the beginning, plastic region reached almost the entire frame. Next, unloading takes place at the upper portion of the plastic region as the 1st mode grew. In Section 5.3, to compare the previous and new criteria, time history analysis is performed for cyclic ground motions. The condition for suppression of deformation concentration derived from the new criterion predicts the response much more accurate than the previous criterion. In Section 5.4, the influence of large rotation and column yielding is investigated. The response was almost the same until the maximum story drift angles reach about 0.2 radian. When the deformation exceeds this limit, geometrically exact analysis provided lower response prediction. Column yielding took place at the height of about a half height of the deformation concentration region. After the column yielding, collapse mechanism is formed whose height is about a half of the deformation concentration region. 